\title{
EFFECT OF PLANTING METHOD AND DENSITY ON YIELD AND QUALITY OF SOME PROMISING SUGARCANE VARIETIES
}

\author{
AYMAN M. ABD EL-RAZEK
}

Sugar Crops Res. Inst., ARC, Giza, Egypt

(Manuscript received 31 October 2011)

\begin{abstract}
Two field experiments were conducted in Mallawi Agricultural Research Station, Minia Governorate during 2009/2010 and 2010/2011 growing seasons to find out the proper panting method (ring or row planting methods) on juice quality traits, cane and sugar yields of four sugarcane varieties (Phil.8013, G.99-103, G.2000-176 and G.84-47). A split plot design with three replications was used in both seasons, where the panting methods and density were allocated in the main plots, while the sugarcane varieties were randomly distributed in the sub-plots. Ring (pit) area was $0.64 \mathrm{~m}^{2}$ (90-cm diameter). Rings were dug to a $45-\mathrm{cm}$ depth. In each ring, $5 \mathrm{~kg}$ farmyard manure was mixed uniformly before placing the setts for planting. Rings were planted with 20, 30 and 40 buds/ring and covered with 2-5 cm soil. Plot area was $35 \mathrm{~m}^{2}$, which consisted of 5 ridges of $1 \mathrm{~m}$ apart and 7 long. Sugarcane varieties were planted in the $1^{\text {st }}$ week of March in both seasons. All agronomic practices were done as recommended for growing sugarcane crop.

Ring planting method recorded a significant increase in stalk height, sucrose $\%$, purity $\%$, sugar recovery $\%$ and cane and sugar yields/fed.

The evaluated sugarcane varieties differed significantly in stalk height, stalk diameter, sucrose $\%$, purity $\%$, sugar recovery $\%$, cane and sugar yields/fed. Sugarcane Phil.8013 and G.84-47 varieties recorded the highest cane and sugar yields/fed.

The interaction between the two factors had significant effects on all studied traits.

Therefore, under conditions of the present work, planting sugarcane varieties Phil.8013 and G.84-47 in rings using 30 buds/ring could be recommended to get the highest cane and sugar yields/fed.
\end{abstract}

\section{INTRODUCTION}

Planting density per unit area has a direct effect on cane and sugar yields. It plays a distinct role on the amount of solar radiation intercepted and hence crop canopy development, which in turn affects photosynthesis and ultimately the dry matter produced by plants. Via the effect on cane diameter, length and weight, as cane yield components. Further, seeding rates play a vital role in defining the number of shoots emerged and mortality. Concerning the influence of seeding rate, El-Shafai (1996) showed that planting sugarcane with two rows (drills) of cane sets (50400 
buds/fed) increased significantly stalk height but decreased its diameter compared with planting 1.5 rows (37800 buds/fed). Planted sugarcane at a density of 30000, 40000 or 50000 sets/ha. Zahoor et. al. (1997) showed that sugar yield was the highest with 40000 sets/ha, while juice quality (pol., purity and sugar content) were not affected by plant density. Bull et. al. (2000) mentioned that the theory behind high density planting (HDP) is based on the fact that current crops intercept less than $60 \%$ of the available solar radiation during the season. They added that HDP significantly increases light interception in the period prior to canopy closure and can also make better use of available water and nutrient resources during this period suggesting that close rows have the potential to increase crop yield of cane per hectare. Moreover, Avtar et. al. (2001) grew sugarcane at seeding rates of 50000 and 75000 three-budded sets/ha. They revealed that higher cane yield was obtained at a seeding rate of 50000 compared to 75000 three-budded sets/ha. Shahid et. al. (2001) studied the effect of different planting densities (100, 150, 200 and 250 thousand buds/ha) on yield of sugarcane. They found that increasing planting rate gave higher cane yield. El-Sogheir and Mohamed (2003) and Ahmed (2005) studied the effect of two seeding rates of 1.5 and 2.0 rows (drills) of cane cuttings. They found that planting sugarcane using 16800 cane setts/fed in two drills attained significantly higher number of millable stalks $/ \mathrm{m}^{2}$, cane and sugar yields compared with 12600 cuttings/fed. Higher values of stalk height, number of millable canes $/ \mathrm{m}^{2}$ and purity $\%$ were significantly obtained by planting two drills. On the contrary, thicker stalks were produced in case of using 12600 cane setts/fed. Dealing with planting methods Muhammad et. al. (2005) studied different planting patterns included $50 \mathrm{~cm}$ apart 100 x $100 \mathrm{~cm}$ pits, $120 \mathrm{~cm}$ apart trench planting, $90 \mathrm{~cm}$ apart double row strips planting and $60 \mathrm{~cm}$ apart single row planting systems. Among the four planting patterns, sugarcane planted at $50 \mathrm{~cm}$ apart $100 \times 100 \mathrm{~cm}$ pits gave the highest cane yield of $149.13 \mathrm{t}$ ha against $120.54,74.67$ and 68.42 tons/ha for $120 \mathrm{~cm}$ apart trench planting, $90 \mathrm{~cm}$ apart double row strips planting and $60 \mathrm{~cm}$ apart single row planting systems, respectively. Sucrose contents $\%$ were not affected significantly by different planting patterns. They concluded that pit planting was superior in all respect. Mahmood et. al. (2007) showed that sugarcane planted in $100 \mathrm{~cm}$ spaced double rows with $60 \mathrm{~cm}$ wide ditches on account of relatively greater number of stripped canes $/ \mathrm{m}^{2}$ and higher weight per stripped cane gave significantly the highest stripped cane yield of 134.81 tons/ha, which was statistically equal to that produced by $100 \mathrm{~cm}$ spaced $100 \times 100 \mathrm{~cm}$ pits planting (132.50 tons/ha). The lowest cane yield of 105.95 tons/ha was recorded for sugarcane planted in $90 \mathrm{~cm}$ spaced single row. Similarly, sucrose contents in cane juice were the highest (18.68\%) in sugarcane planted in 90 
$\mathrm{cm}$ spaced double-row strips followed by that planted in $90 \mathrm{~cm}$ spaced single rows (18.63\%) against the lowest $18.44 \%$ in that planted in $100 \mathrm{~cm}$ spaced triple rows with $90 \mathrm{~cm}$ wide ditches. Singh et. al. ( 2008) revealed that the highest cane length (253.2 $\mathrm{cm})$, cane girth $(3.09 \mathrm{~cm})$, cane weight $(1.30 \mathrm{~kg})$ and cane yield $(87.6$ tons/ha) as well as sugar yield (9.87 tons/ha) were recorded under ring-pit $(75 \mathrm{~cm}$ diameter and $45 \mathrm{~cm}$ depth at $120 \mathrm{~cm}$ spacing) planting method. This was closely followed by trench method (120 cm apart, $45 \mathrm{~cm}$ deep trenches). However, the highest number of tillers (242.8 thousand/ha) and millable canes (149.4 thousand/ha) were counted in sugarcane planted at $60 \mathrm{~cm}$ row spacing. Sukera et. al. (2009) studied the effect of ring (pit) as planting technique of sugarcane. They obtained improvement in germination, millable canes and cane yield/ha as compared to conventional planting.

Regarding cane varieties effect, In Egypt, Ahmed (2000) evaluated five sugarcane genotypes (G.85-37, G.84-47, F.153, G.75-368 and G.87-55) compared with the commercial variety G.T. 54-9. He found that the tested cane varieties were significantly different in cane and sugar yields. Yousef et. al. (2000) revealed that sugarcane varieties differed significantly in millable cane length, diameter and cane yield. Mohamed and Ahmed (2002) obtained significant differences among the studied cane varieties in stalk height, diameter and net cane and sugar yields. Ahmed (2003a) revealed that the promising sugarcane varieties G.95-19, G.95-21 and ph.8013 differed markedly in millable cane height, diameter, sucrose $\%$ and sugar yield. $\mathrm{He}$ mentioned that the differences among varieties could be to the relative importance of gene make-up.

The present study, therefore, aimed at finding the effect of planting sugarcane in pits using different number of buds $/ \mathrm{m}^{2}$ compassed with the conventional method in ridges on yield and quality of four promising sugarcane varieties.

\section{MATERIALS AND METHODS}

Two field experiments were conducted in Mallawi Agricultural Research Station, Minia Governorate during 2009/2010 and 2010/2011 growing seasons (as plant cane) to find out the proper panting method (ring and row planting methods) and density on juice quality traits, cane and sugar yields of four sugarcane varieties (Phil.8013, G.99-103, G.2000-176 and G.84-47). A split plot design with three replications was used in both seasons, where the planting methods and density were allocated in the main plots, while the sugarcane varieties were randomly distributed in the sub-plots. Ring (pit) area was $0.64 \mathrm{~m}^{2}$ (90-cm diameter). Rings were dug to a 45$\mathrm{cm}$ depth. In each ring, $5 \mathrm{~kg}$ farmyard manure was mixed uniformly before placing the setts for planting fig (1). Rings were planted with 20, 30 and 40 buds/ring and 
covered with 2-5 cm soil. These ring planting densities were compared with the conventional ridge planting density of $12 \mathrm{bud} / \mathrm{m}^{2}$. Plot area was $35 \mathrm{~m}^{2}$, which consisted of 5 ridges of $1 \mathrm{~m}$ apart and 7 long. Sugarcane varieties were planted in the $1^{\text {st }}$ week of March in both seasons. All agronomic practices were done as recommended for growing sugarcane crop.

\section{The recorded data:}

1. Stalk cane height $(\mathrm{cm})$ was measured from soil surface up to the top visible dewlap.

2. Stalk cane diameter $(\mathrm{cm})$ was measured at the middle internode of stalks.

3. Stalk cane weight $(\mathrm{kg})$.

4. Sucrose percentage in juice was determined using Saccharemeter apparatus according to A.O.A.C. (1995).

5. Sugar recovery percentage was calculated according to the following formula described by Yadav and Sharma (1980).

Sugar recovery $\%=[$ Sucrose $\%-0.4($ brix $\%$ - sucrose $\%)] \times 0.73$

6. Cane yield (tons/fed).

7. Sugar yield (tons/fed) was estimated as follows:

Sugar yield (tons/fed) $=$ cane yield (tons/fed) $\mathrm{x}$ sugar recovery $\%$.

The collected data were statistically analysed according to the method described by Snedecor and Cochran (1981).

\section{RESULTS AND DISCUSSION}

\section{Stalk height and diameter:}

Data in Table 1 showed that increasing planting density in the ring planting method from 20 to 30 and 40 buds/ring led to a gradual and significant increase in cane stalk height. This result could be due to the competition among cane plants for light in the dense planting. Chang (1974) reported that the proportion of invisible solar radiation is so much increased than the visible solar radiation due to dense sowing. The former has an elongating effect and hence accounts for the increase observed in stalk height when sugarcane was planted in dense planting. On the contrary, increasing planting density in the ring planting method was accompanied with a reduction in stalk diameter probably may be due to the competition among plants for light, nutrients and space. Similar results were reported by singh et. al. (2008) and Yadav et. al. (2009). Moreover, the ring planting resulted in taller stalks and thinner ones compared with the normal method of planting, i.e. planting sugarcane in ridges. This result could be attributed to lower number of buds $/ \mathrm{m}^{2}$ in case of the ridge planting. 
Table (1) 
Data in Table 1 indicate that the evaluated sugarcane varieties differed significantly in stalk height and diameter in the $1^{\text {st }}$ and $2^{\text {nd }}$ seasons. In both seasons, sugarcane G.84-47 variety showed the tallest stalk height over the other varieties, while G.200-176 had the shortest stalks. These results are in agreement with those found by Ahmed (2000). Moreover, Phil.8013 variety had the thickest stalks, while G.99-103 variety recorded the thinnest as compared with the other ones. The differences among the tested cvs may be due to their gene make-up.

Concerning the interaction effect, results in Table 1 showed a significant influence on cane stalk height due to the interactions among sugarcane varieties and planting methods in both seasons. In the $1^{\text {st }}$ one, it was noticed that the differences in stalk height of the tested varieties were insignificant in case of planting them using 20 buds/ring and conventionally method (in ridges using 12 buds $/ \mathrm{m}^{2}$. In the $2^{\text {nd }}$ season, the differences in stalk height were significant both planting methods or densities except between Phil.8013 and G.84-47 when both were planted using 20 buds/ring or conventionally in rows was insignificant.

Data in Table 1 pointed to a significant effect on cane stalk diameter due to the interaction among sugarcane varieties and planting methods in both seasons. Phil. 8013 sugarcane variety recorded the thickest stalks, when planted in ridges planting methods using $12 \mathrm{bud} / \mathrm{m}^{2}$.

\section{Stalk weight and number of millable canes:}

Data in Table 2 showed that increasing planting density in the ring planting method from 20 to 30 and 40 buds/ring caused a gradual and significant reduction in stalk weight (Table 2). This result could be attributed to the intensive competition among cane plants for growth factors, i.e. water, nutrients, light and space. These results are in line with those reported by Chang (1974) and Bull et. al. (2000). Contrary results were found with respect to number of millable canes $/ \mathrm{m}^{2}$ due to the increase of planting density in the ring planting method probably due increasing planting material, i.e. number of buds $/ \mathrm{m}^{2}$. These results coincide with those mentioned by El-Sogheir and Mohamed (2003) and Ahmed (2005). 
Table (2) 
Moreover, planting sugarcane conventionally, i.e. planting it in rows resulted in the heaviest stalks (in both seasons) and lowest number of millable canes $/ \mathrm{m}^{2}$ (in the $2^{\text {nd }}$ season) compared with the ring planting. This result could be due to lower number of buds $/ \mathrm{m}^{2}$ used for planting sugarcane in ridges. These results are in harmony with those reported by Mahmood et. al. (2007) and Sureka et. al. (2009).

Data in Table 2 pointed to significant differences among the tested sugarcane varieties in stalk weight and number of millable canes $/ \mathrm{m}^{2}$ in both seasons. Phil.8013 variety had the heaviest stalks. Such effect may be due to thickest stalk recorded by the same variety (Table 2). On the contrary, G.99-103 exhibited the lightest stalk weight. In addition the other two varieties G. 200-176 and G. 84-47 were between those limits in both seasons.

The results in Table 2 indicated that G.84-47 variety had the highest tillering ability, where it produced the highest number of millable canes $/ \mathrm{m}^{2}$, while G.200-176 had the lowest value of this trait, without significant difference with Ph.8013. These results were true in both seasons.

The differences among the tested cvs in stalk weight and number of millable canes $/ \mathrm{m}^{2}$ may be due to their genetic structure. These results are in agreement with those given by Yousef et. al. (2000), Ahmed (2003-a).

The interaction among varieties, planting methods and densities had a significant effect on stalk weight in both seasons (Table 2). Phil. 8013 sugarcane variety recorded the heaviest stalks, when planted in ridges planting methods using 12 bud $/ m^{2}$.

Results in Table 2 indicated that the interaction between sugarcane varieties and planting methods had a significant effect number of millable canes $/ \mathrm{m}^{2}$ in both seasons. In the $1^{\text {st }}$ one, the differences in number of millable canes $/ \mathrm{m}^{2}$ of $\mathrm{G} .84-47$ variety were insignificant in case of planting it using 30 buds/ring or conventionally in rows using 12 buds $/ \mathrm{m}^{2}$, while the differences between these two methods in their effect on this trait were significant for the other tested cane varieties. Similar results were observed in the $2^{\text {nd }}$ season, where the variance in number of millable canes $/ \mathrm{m}^{2}$ of G.84-47 variety was insignificant by planting it using 20 buds in ring method or $12 / \mathrm{m}^{2}$ arranged in ridges, while the differences between these two methods in their effect on this trait were significant for the other varieties. 
Table (3) 
Table (4) 


\section{Sucrose, purity and sugar recovery percentages:}

Data in Tables (3) and (4) pointed to a significant reduction tendency in sucrose, purity and sugar recovery percentages as planting density was increased from 20 to 30 and 40 buds/ring in case of planting cane using ring method in both seasons. This result may be due to unfavourable conditions for plant growth as a result of higher competition among plants as plant density increased, which was reflected negatively on sugar synthesis and accumulation. These results are in harmony with those mentioned by Muhammad et. al. ( 2005), Mahmood et. al. (2007). Further, planting sugarcane conventionally in ridges resulted in the highest values of the studied quality traits without significant variance in sucrose $\%$ (in the $1^{\text {st }}$ season) and sugar recovery $\%$ (in both seasons) with that planted using ring method using 30 buds/ring.

Data in the Tables (3) and (4) manifested significant differences in the studied quality characteristics in the $1^{\text {st }}$ and $2^{\text {nd }}$ seasons. The variety G.84-47 showed the highest values of sucrose, purity and sugar recovery percentages compared with the other sugarcane varieties. Meanwhile, G.2000-176 variety recoded the lowest sucrose and sugar recovery percentages, while the lowest purity \% was given by G.99-160. Moreover, insignificant variance in sucrose \% was found between G.99-103 and G.2000-176 cane varieties in the $2^{\text {nd }}$ season. Also, insignificant difference in sugar recovery \% was detected between Phil.8013 and G.84-47 in both seasons. The differences among the examined varieties in those traits may be due to mainly their gene make-up. These results are in line with those reported by Yousef et. al. (2000) andAhmed (2003-a).

Data in Table 4 show that sucrose \% was significantly influenced by the interactions among sugarcane varieties and planting methods in both seasons. The results revealed that the differences in sucrose $\%$ of the tested varieties were insignificant in case of planting them in ring method by 20 buds/pit or in ridges using $12 \mathrm{buds} / \mathrm{m}^{2}$. However, the difference between the latter and $40 \mathrm{buds} / \mathrm{pit}$ in sucrose $\%$ reached the level of significance mostly for all varieties with a superiority of the conventional planting method in this trait.

Significant effect of the interactions between sugarcane varieties and planting methods on purity in both seasons have been recorded (Table 3 and 4). It was noticed that except for Ph.8013 variety (in the $1^{\text {st }}$ season) and G.99-103 (in the $2^{\text {nd }}$ one), the differences in purity\% of any of the other cane varieties were insignificant when they were planted in rings using 20 buds/pit or in ridges using $12 \mathrm{buds} / \mathrm{m}^{2}$ with higher values of this trait in the ridge method.

Data in Table 3 indicated that sugar recovery \% was significantly influenced by the interactions between sugarcane varieties and planting methods in both seasons. 
The results showed that except for G.200-176 variety (in both seasons) and G.99-103 (in the $2^{\text {nd }}$ one), the differences in sugar recovery of any of the other cane varieties were significant in case of planting them in rings using 20 or 40 buds/pit, with higher values of this trait in the lower density.

\section{Cane and sugar yields/fed:}

Data in Table 5 indicated that effect of planting method and density, the highest cane and sugar yields were obtained by planting sugarcane with 30 buds/ring. Planting sugarcane using this method out yielded the other densities of using 20 buds and 40 buds/ring or that planted in ridges using $12 \mathrm{buds} / \mathrm{m}^{2}$ by $22.83,19.22$ and 26.43 tons of canes/fed in the $1^{\text {st }}$ season, corresponding to $34.35,20.72$ and 28.17 tons/fed in the $2^{\text {nd }}$ season, respectively. These results are in line with those mentioned by Singh et. al. ( 2008) and Sukera et. al. (2009) Planting sugarcane in rings using 30 buds/ring surpassed planted cane in rings using 20 and 40 buds/ring or that planted in rows using 12 buds $/ \mathrm{m}^{2}$, by $1.84,2.44$ and 2.21 ton/fed in the $1^{\text {st }}$ season and by 2.03, 2.68 and 2.38 ton/fed in the second season, respectively. However, insignificant difference in sugar yield was found in case of planting sugarcane in rings using 40 buds/ring or planted in ridges using $12 \mathrm{buds} / \mathrm{m}^{2}$, in the $1^{\text {st }}$ season. Also, the difference in sugar yield was insignificant when sugarcane was planted in rings using 30 buds/ring or that planted conventionally in ridges. These results coincide with those obtained by Singh et. al. (2008) and Sukera et. al. (2009).

The results in Table 5 cleared that the evaluated sugarcane varieties varied significantly in cane and sugar yields/fed in the $1^{\text {st }}$ and $2^{\text {nd }}$ seasons. Cane variety Phil.8013 produced the highest cane/fed (in both seasons) and sugar yields/fed (in the $1^{\text {st }}$ one), while, G.2000-176 gave the lowest ones. Phil.8013 variety was exceeded G.99-103, G.2000-176 and G.84-47 by 5.24, 7.78 and 3.69 tons/fed, respectively, in the $1^{\text {st }}$ season, corresponding to $5.50,8.81$ and 3.28 tons/fed, in the $2^{\text {nd }}$ one. Likewise, Phil.8013 variety produced $1.13,1.68$ and 0.12 ton of sugar/fed higher than that extracted from G.99-103, G.2000-176 and G.84-47, successively, in the $1^{\text {st }}$ season. In the $2^{\text {nd }}$ one, G.84-47 variety recorded $0.49,1.41$ and 2.40 ton sugar/fed compared with Phil.8013, G.99-103, G.2000-176, respectively. These results are in agreement with those reported by Yousef et. al. (2000), Mohamed and Ahmed (2002) and Ahmed (2003-a). Meantime, insignificant difference between Phil.8013 and G.8447 varieties in sugar yield was noticed in both seasons. Such effect may be due to that those two varieties characterized with higher values of sucrose and sugar recovery percentages (Table 3 ) and cane yield/fed (Table 5). 
Table (5) 

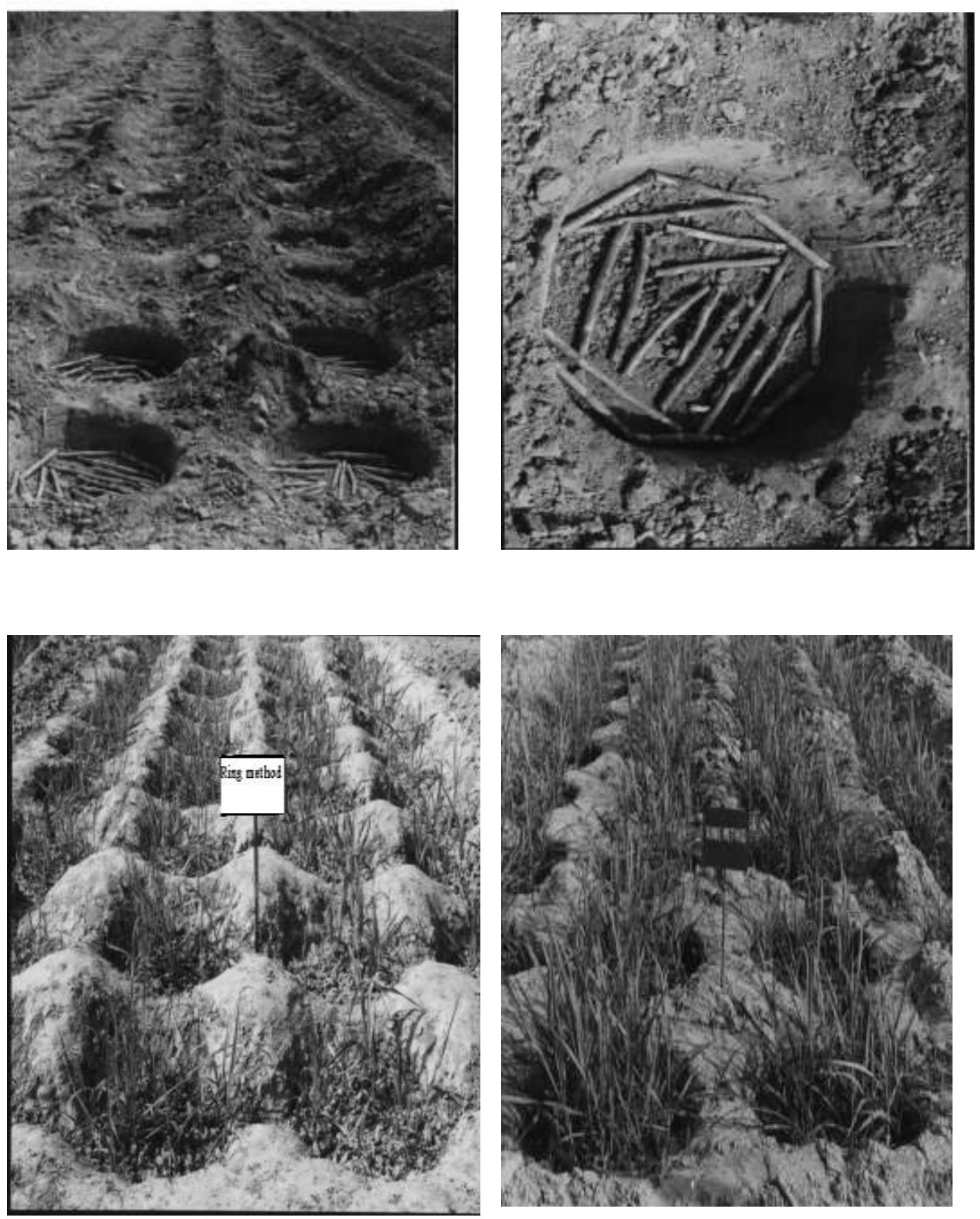

Fig . (1) : Showing the ring planting method. 
The interaction between cane varieties and planting methods (Table 5) showed that Phil 8013 variety exhibited the highest cane yield (ton/fed) in both seasons when planted in 30 bud/ring, while G. 200-176 exhibited the lowest cane yield under conventional planting methods in both seasons also. In general, planting cane using the new method pits (Rings area $64 \mathrm{~m}_{2}, 90 \mathrm{~cm}$ diameter and $45 \mathrm{~cm}$ depth) greatly surpassed those of conventional method (Table 5 ).

The results in Table 13 showed a significant influence on sugar yield/fed trait due to the interactions between sugarcane varieties and planting methods in both seasons. In the $1^{\text {st }}$ one, the differences of any of the evaluated varieties in sugar yields were insignificant in case of planting them using 40 buds/ring or conventionally in ridges using 12 buds $/ \mathrm{m}^{2}$. However, the differences between planting methods in its effect on sugar yield reached the level of significance when any cane variety was planted in rings using 20 and/or 30 buds/pit. The same trend was observed in the $2^{\text {nd }}$ season.

\section{CONCLUSION}

Under the conditions of the present work, planting Phil.8013 and G.84-47 cane varieties in rings using 30 buds/ring can be recommended to get the highest cane and sugar yields/fed.

\section{REFERENCES}

1. Ahmed A. M. 2005. Effect of seeding rate and nitrogen fertilization level on yield and quality of two sugarcane cultivars. Egypt. J. Appl. Sci., 20 (11):116-132.

2. Ahmed A. Z. 2000. Stability of new sugarcane varieties. Proc. $2^{\text {nd }}$ Arab Conf. Genet. Biotec., Oct. 23-26: 449-455. Minia Univ., Minia, Egypt.

3. Ahmed A. Z. 2003-a. Assessment of the optimum nitrogen level and seeding rate for two promising sugarcane varieties. Egypt. J. Appl. Sci., 18 (6-b):559-573.

4. A.O.A.C. 1995.Official methods of analysis published by the Association of Official Agricultural Chemist, Box 540, Washington.

5. Avtar S., S. Rajbahadur, A. Singh and R. Singh. 2001. Effect of agronomic practices on the productivity of late planted sugarcane. Crop Res. Hisar., 21(2): 123-125.

6. Bull, T. A., J. K. Bull and D. M. Hogarth. 2000. High density planting as an economic production strategy: (b) theory and trial results. Proc. The 2000 Conf. The Australian Soc. Sugar Cane Technol. Held at Bundaberg, Queensland, Australia, 2-5 May, 2000. Vol. 2, pp. 104-112.

7. Chang, J. H. 1974. Radiation distribution within the plant community: 36-42. Climate and Agriculture, Aldine Publishing Company, Chicago, Illinois, USA.

8. El-Shafai, A. M. A. 1996. Water requirements of sugarcane under different levels of nitrogen fertilization. Ph.D. Thesis, Agron. Dept., Fac. Agric. Moshtohor, Zagazig Univ., Egypt. 
9. El-Sogheir, K. S. and A. M. Mohamed. 2003. Optimal seed rate for some Promising sugarcane varieties. Egypt. J. Agric. Res., 81(4): 2003, pp. 16931705.

10. Mahmood, A., M. Ishfaq, J. Iqbal and M. Shafi Nazar. 2007. Agronomic Performance and Juice Quality of Autumn Planted Sugarcane (Saccharum officinarum L.) as Affected by Flat, Ditch and Pit Planting Under Different Spatial Arrangements. Int. J. Agri. Biol. Pakistan , 9(1): 167-169.

11. Mohamed, B. D. and A. Z. Ahmed. 2002. Influence of planting seasons and nitrogen fertilizer levels on productivity of three sugar cane varieties. Egypt. Appl. Sci., 17(3): 64-77.

12. Muhammad M., M. Iqbal and M. Tayyab. 2005. Comparative productivity performance of Sugarane (Saccharum officinarum L.) sown in different planting patterns at farmers field. Pakistan J. Agri. Sci. 42 (4):25-28.

13. Shahid, B., M. Saeed, S. Bashir and M. Saeed. 2001. Effect of planting pattern and seeding density on yield, weed mass production and crop lodging in sugarcane cv. SPSG-394. Pakistan Sugar J., 16(1): 9-13.

14. Singh A. K., Lal Menhi, Singh Ishwar, R. L. Yadavand D. V. Yadav. 2008. Effect of planting method and drought-management technique on growth, yield and quality of sugarcane (Saccharum hybrid complex) under limited irrigation. Indian J. Agron., 53(3).

15. Snedecor, G. W. and W. G. Cochran. 1981. Statistical Methods. Seventh Ed., Iowa State Univ. Press, Ames, Iowa, USA.

16. Sureka, B. K., V.P. Shahi, I.S. Singh and Narenda Singh. 2009. Ring pit planting technique of sugarcane adopted to increase cane productivity at Bharat sugar mills, Sidhwalia, Gopalganj, Bihar. Indian Sugar, 59(9): 69-74.

17. Yadav, R. L. and R. K. Sharma. 1980. Effect of nitrogen level and harvesting date on quality characteristics and yield of four sugar cane genotypes. Indian J. Agric. Sci., 50: 581-589.

18. Yadav, R. L., Ravi Kumar and R. S. Varma. 2009. Effect of Planting Technique and Planting Density on Yield of Late Planted Sugarcane in North Central India. Indian Sugar, 59(9): 92-99.

19. Yousef M. A., E. M. Taha and A. Z. Ahmed. 2000. Influence of some cultural practices on yield and yield components of some sugar cane varieties. Egypt. J. Agric. Res. 78(5): 2000.

20. Zahoor, A., K. Sherin, R. Said, A. Gulzar and K. Dawa. 1997. Yield and quality of sugarcane as affected by different levels of nitrogen and planting density. Pakistan Sugar J., 11(2):29-33. 


\section{تأثير طريقه وكثافة الزراعة على محصول وجودة بعض اصناف قصب السكر المبشرة}

ايمن محمد عبد الرازق

$$
\text { معهز بحوث المحاصيل السكرية - مركز البحوث الزراعية - جيزة - مصر }
$$

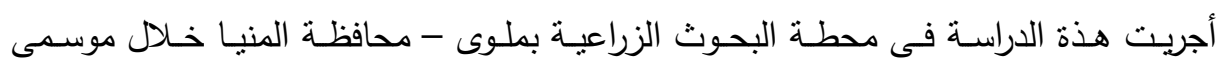

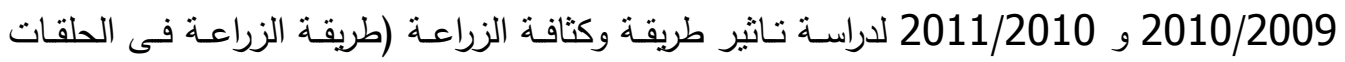

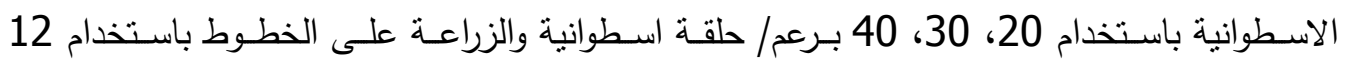

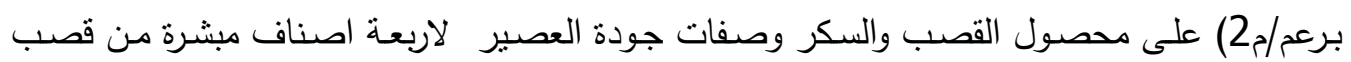
السكر (الفلبينى 8013 ، جيزة 103-99، جيزة 176 170-2000 ، جيزة 47-84).

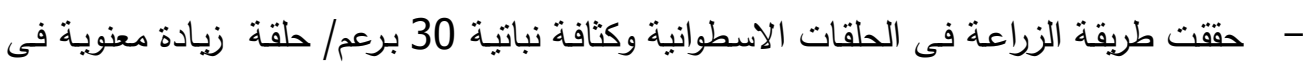

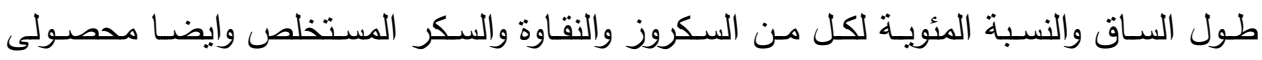
القصب والسكر /فدان مقارنة بطريقة الزراعة التقليدية فى خطوط باستخدام 12 برعم/ح2. - - اوضحت الدراسة وجود اختلاف معنوى بين الاصناف فى صفة طول وقطر الساق والنسبة المئوية لكل من السكروز والنقاوة والسكر المستخلص ومحصولى القصب والسكر وسجل الصنفين الفلبينى 8013 وجيزة 47- 84 اعلى محصول من القصب والنعرون والسكر /فدان. - اظهر التفاعل بين العوامل نأثيرا معنويا على كل الصفات المدروسة.

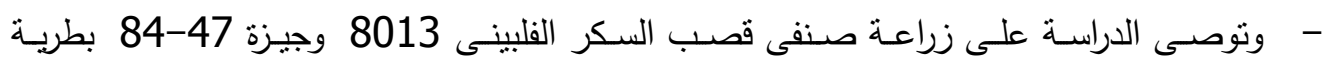
الحلقات الاسطوانية وكثافة نباتية 30 برعم / حلقة للحصول على اعلى محصول من القصب لكب 